\title{
The Same in Polish, or Peculiarities of Bilingual Occasional Poetry in the Eighteenth-century Grand Duchy of Lithuania
}

\author{
ASTA VAŠKELIENĖ
}

\begin{abstract}
The paper addresses eighteenth-century occasional poetry of Lithuania written in parallel Latin and Polish. The research seeks to draw attention to bilingual creation as a literary phenomenon that reflects the linguistic priorities and cultural needs of the time, and to reveal the most distinct semantic and artistic peculiarities of bilingual occasional poetry. As a phenomenon of Lithuanian neo-Latin literature, bilingualism has not yet been addressed in detail in scholarly historiography. Only an article by Eugenija Ulčinaite, in which she introduces linguistic expression, semantics and stylistics of sixteenth to seventeenth-century Lithuanian bilingual texts is devoted to this thematic. Research in eighteenth-century occasional poetry of the Grand Duchy of Lithuania has shown that parallel texts occur in nearly all poetry genres, but they were most popular among epigrams. Language variants of the works can be written both by the same and by different authors. Comparative analysis of texts has shown that when the primary Latin - content is conveyed in Polish, it can be modified or complemented with information relevant to the dedicatee. Such alteration causes semantic and stylistic differences and creates a shift in the emotional tone of a work. Despite the fact that both - Latin and Polish - versions of a work are officially dedicated to the same dedicatee, the group of recipients seems expanded. It is quite possible that the Latin version is addressed to the individual named in the title, while the Polish version is meant for the general public or people lacking in education necessary to understand the Latin text. The need to convey the same content in Polish points to the vitality of occasional literature and its universally perceived purpose.
\end{abstract}

Keywords: eighteenth-century bilingual literature; parallel texts; neo-Latin occasional poetry; Grand Duchy of Lithuania

Eighteenth-century bilingual occasional poetry of the Grand Duchy of Lithuania makes up a specific part of the literary heritage that is important for the understanding of cultural processes. Bilingual works are those the Latin version of which is accompanied by their parallel versions in Polish. The Polish 
version can often be considered a word-for-word translation of the Latin text; we, however, were interested in the cases when the work in Polish, which its author called 'Toż samo po polsku' ('The Same in Polish'), or simply 'Toż samo', differed slightly from the Latin text in semantic and stylistic aspects. It is these works that we have selected for analysis. Bilingual parallel occasional texts pose a number of questions: when did such texts start to function, how many of them exist and in what languages, apart from Latin and Polish mentioned above, were they written; is it possible to distinguish a dominant genre group, and were they the works by one or by different authors?

As this field has not been adequately researched, the chronological boundaries of parallel poetry can be defined only hypothetically. We have to rely on facts which only accidentally, and not by way of purposeful analysis, enter the field of vision. Such experience allows us to link the sources of bilingual works with the late sixteenth century. One of the examples that substantiates this claim is the bilingual occasional poems, mostly epigrams, in Motiejus Strijkovkis' (Matthias Stricovius, Maciej Stryjkowski, ca 1547-ca 1593) Kronika Polska Litewska, Zmodzka, y wszystkiey Rusi Kijowskiey' ('Chronicle of Poland, Lithuania, Samogitia, and all of Ruthenia of Kiev'), first published in Karaliaučius (Königsberg) in 1582. Bearing in mind the fact that before its publication the Kronika was disseminated in the manuscript form, the date of the functioning of bilingual texts can be back dated and we can assume that they circulated as early as the last quarter of the sixteenth century. Bilingual occasional works were also written in the seventeenth century, while from the middle of the eighteenth century they appear with greater frequency. Since these works are closely related to the tradition of occasional literature, the need for them was diminishing along with ever-weakening Latin culture.

According to Irena Petrauskiene's research, the print shop of the Vilnius Academy (which was one of major book publishing centres in Lithuania at the time) published 2549 publications in the eighteenth century, and 80 of them were bilingual (Petrauskiene 1976: 183). Unfortunately, this number does not help our research since it does not provide any information about the languages in which these works were written, their purpose, and their genres. Whether the texts of these multilingual publications are semantically adequate is even less clear. A de visu overview of occasional publications of this type suggests that the majority of them were written particularly in Latin and Polish. It should be stressed that there also exist variants where when the parallel texts

1 See the list of bibliography for the full title. 
are written in French, German, Italian, or other languages ${ }^{2}$, but such works lie outside the scope of this paper.

From the genre point of view, it should be noted that parallel texts are most of all characteristic of epigrams, and are less frequent among odes, elegies, or epitaphs. Thus, parallel works can be found among all genres of eighteenthcentury occasional poetry with the exception of works in hexameter that in their volume are closer to epic poems (such works in Latin are few in number).

According to the tradition of that time, bilingual works, like other texts of occasional literature, could be published without authorial attribution; also, their language variants could be penned by one or by different authors. One of the questions that we sought to answer with our analysis of bilingual poetry was the following: who - the author (authors) or the dedicatee of a work - exerts a stronger influence on the semantic and poetic expression of a parallel text?

It should be noted that this type of occasional literature has been poorly researched. Not a single paper or a study has so far been written about eighteenthcentury parallel texts. As for the earlier period, there is mention of it in just one work - Eugenija Ulčinaitës paper that appeared almost ten years ago. The work, which 'did not claim to present an exhaustive discussion but, rather, to highlight the problem' analyzes sixteenth-seventeenth-century Latin poetry and prose works ${ }^{3}$ of the Grand Duchy of Lithuania published with parallel versions in Polish (Ulčinaitè 2006: 63-79). Having carried out a comparative analysis of bilingual texts, Ulčinaite arrived at the conclusion that the parallel variants were not translations from one language to another but constituted two independent works intended for different addressees. In composing these works authors follow different structure, select different lexicon and phraseology, and highlight different accents of meaning (Ulčinaitè 2006: 77).

2 Probably the most impressive example of eighteenth-century multilingual work is the literary gratulation Universitas linguarum magno Palaemonii orbis hospiti ('The Universe of Speeches for the Most Distinguished Visitor to the World and City of Palemon') published in Vilnius in 1729. It is a collection of poems dedicated to Kristupas Jonas Šembekas (Krzysztof Jan Szembek, 1680-1740), Bishop of Warmia and Sembia, on his visit to Vilnius. The poems in this collection are written in Hebrew, Greek, Latin, Slavonic, Polish, French, German, Lithuanian, and Latvian languages. Some of them are given with Latin paraphrases, others with parallel variants in other languages. For example, the texts in Slavonic and Lithuanian are accompanied by their versions in Polish. Interestingly, their titles, no matter how short, are given in Latin: 'Id est', that is, 'The same [in Polish]'.

3 Eugenija Ulčinaite supports her paper with the poem-dialogue Philopatris ad senatum populumque Lituanum ('A Lover of the Homeland to the Senate and the Nation of Lithuania', 1597) by Elijus Pilgrimovijus (Elias Pilgrimovijus, Pielgrzymowski, Pilgrzymowski, [?]-1604) and some seventeenth-century publications of Vilnius Jesuit academy. 
We will introduce the specific nature of eighteenth-century bilingual occasional poetry of the Grand Duchy of Lithuania with several epigrams, which were included in the posthumous poetry collection Carmina ${ }^{4}$ by the Jesuit Mykolas Korickis (Michael Korycki, Michał Korycki, 1714-1781), a poet of Lithuanian origin. The collection was compiled by members of the Society of Jesus and published in Polotsk in 1817. Another publication we have consulted is the Illustrissimo [...] Ignatio [...] Massalski ${ }^{5}$, an anonymous poetry collection dedicated to the consecration of the Bishop of Vilnius, Ignatius Masalskis, and published in Vilnius in 1762.

In Jesuit historiography, Mykolas Korickis is introduced as a poet who wrote in Latin and who had won the recognition and appreciation of his contemporaries. Korickis wrote most of his works as poetical correspondence with prominent politicians and cultural figures of the day (Encyklopedia 1996: 305). The part of his literary legacy included in the collection Carmina bears witness to the talent that distinguished him from other poets of the eighteenth century. Evidence of this skill can be seen in the variety of poetical genres in his work: the collection is dominated by poems, songs, elegies, odes and epigrams; it includes some eclogues, fables, dithyrambs, leonine verse ${ }^{6}$ and Dirae ${ }^{7}$, or 'the poetry of blame'. Korickis makes allusions to the poets of antiquity and the early modern period (for instance, Virgil and Sarbievius); he invokes classical realities and links them ingeniously with the country's political, social, and cultural topical issues. Only very few of the Latin poems have parallel Polish variants. One of the examples is a cycle of epigrams on the coronation of Stanislaw August.

4 Full title: Michaelis Korycki Societatis Jesu Sacerdotis Carmina.

5 Full title: Illustrissimo [...] Ignatio [...] Massalski, episcopo Vilnensi, Academia et Universitas Vilnensis S. I. tanquam suo cancellario in ejus solemni consecratione plaudens A. 1762 d. 2 Maji.

6 Leonine verse (Lat. versus leoninus) is a genre of medieval Latin poetry. It is a poem usually written in hexameter and pentameter, with internal rhymes that link the word preceding the caesura with the last word in the line. There are sporadic examples of leonine verse in the early and classical Roman poetry (for instance, Ovid's Ars amandi). The name of the genre is linked to the twelfth-century French poet Léonin (OkopieńSławińska 2008: 274). Leonine verse is attributed to constrained writings (poesis artificiosa) and epic poetry (poesis epica) (Michałowska 1974: 177).

7 Dirae (Lat. unlucky omens, curses) are the works in Latin poetry that express curses, blame, and perdition; the traditional metres of this poetry are hexameter and elegiac distich (Kostkiewiczowa 2008: 101). Dido's monologue in Virgil's Aeneid (IV, 590629), or Horace's seventh epode are usually quoted as typical examples. Dirae is attributed to satirical poetry (poesis satyrica), epic poetry (poesis epica), and panegyric poetry (poesis panegyrica) (Michałowska 1974: 166). 
VAŠKELIENE்

The first five epigrams are dedicated to the festive fireworks in Warsaw in honour of the king ('In Ignes festivos in Urbe Metropoli Varsavia excitatos die Coronationis Stanislai Augusti Regis Polonarium'), the sixth and the seventh to the Siren, the symbol in Warsaw's coat of arms ('Siren Insigne Varsaviae'). The cycle-closing epigrams marked by number eight can be divided into two thematic branches: the first four poems are dedicated 'Ad Serenissimum Regem' (to 'The Most Serene King'), while the last two to the coats of arms of Poland, Lithuania, and King Stanislaw August ('In Insignia Poloniae, Litvaniae et Regis: ad Polonos'). Before moving on to the analysis of the texts, it is worth noting that Korickis might have been in Warsaw during the coronation of Stanislaw August since he was a rector of Warsaw Collegium from 1763 to 1766 (Encyklopedia 1996: 305). It is very likely that he had actually seen the fireworks he describes so vividly.

In the epigram 'In Ignes festivos [...]' ('On festive fireworks set off on the day of Stanislaw August's coronation') the poet compares burning Troy with Warsaw, which is illuminated by the flames of the fireworks:

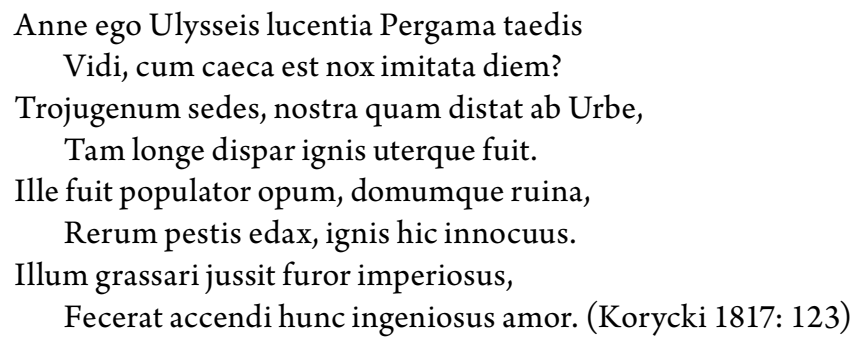

(Did I really see Pergamon blazing with Ulixes' torches, when a dark night became like a day? The site of the Trojans is as far away from our city as various flames differ one from another. One was the destroyer of everything, the pillager of homes, an insatiable glutton of wealth, while this fire is harmless. That flame was sparked by tyrannical fury, and this one was started by ingenious love. ${ }^{8}$ )

Let us now compare the Latin epigram with its Polish version, which has the title 'Toż samo':

Czym widział iasną Troię od greckich płomieni, Gdy świeciła Warszawa pośrzod nocnych cieni?

Iak dalekie siedlisko Troi od Warszawy,

8 This and all other quoted fragments were translated from Latin or Polish by the author of the present paper. 
The Same in Polish, or Peculiarities of Bilingual Occasional Poetry

Tak tamten i ten ogień był różney postawy.

Tamten po wszystkich domach wszystko trawiąc chodzil,

A ten ogień niewinny nikomu nie szkodził.

Tamten ogień wznieciła iędza zapalczywa,

A ten miłość dowcipna i Panu życzliwa. ${ }^{9}$ (Korycki 1817: 123)

(Did I really see Troy lucid with Greek flames, when Warsaw was shining in the dark of night? The city of Troy is as far away from Warsaw as that flame differs from this one. That other spreads in the house swallowing everything, while this one is not angry, it's harmless. That fire was caused by fury, while this one is ingenious love favouring the Master [Stanislaw August].)

Although the differences are insignificant, they are characteristic of bilingual poetry: in the Latin epigram we see Ulixes as a representative of all the Achaeans, and Pergamus as a synonym of Troy. The poet uses the Latin Urbs in reference to Warsaw. Suppressing the apposition Varsavia, which suggests itself by the analogy with Urbs Roma, the Polish capital is characterized as additional shades of meaning which create its image as the most important city. In the Polish version of the poem, Pergamus is replaced by Troy, Ulixes' torches by the flames started by Greeks, and the capital is directly referred to as Warsaw. The Polish translation does not digress from the original content, but stylistic differences bring the Latin variant of the poem closer to the classical context.

Similar differences can be seen in the fifth epigram of the cycle:

Omnia splendor habet. Collucet Palladis aula, Urbs rutilat, radiat curia, templa micant.

Cuncta colunt Regem: sapientem Palladis aula, Urbs Patrem, justum curia, templa pium. (Korycki 1817: 125)

(Everything is shimmering. The Pallas palace is sparkling, the city glimmering, the town hall gleaming, the churches are twinkling. Everyone is lauding the king: The Pallas palace lauds [him] as a wise man, the city as a father, the town hall as a legitimately elected, and the churches as a pious.)

Let us have a look at how the same content is rendered in Polish:

Wszędzie wesołe ognie: iaśnieie Warszawa, Miasto, szkoły, kościoły, ratusz blask wydawa.

Miasto Króla swym mieni Oycem, mądrym szkoły,

A ratusz sprawiedliwym, pobożnym kościoły. (Korycki 1817: 125)

9 Original spelling and punctuation are preserved when citing old Polish texts. 
(Merry flames everywhere: Warsaw, the city, schools, and churches are shining, the town hall is shimmering. The city titles the king its father, schools name him a wise man, the town hall calls him the righteous, and the churches the pious.)

In addition to the poet's choice of the word 'city' (Urbs) in the Latin text and the direct reference 'Warsaw' in the Polish text, the reader's attention is drawn to the author's ingenuity in describing schools. In the Polish text, the poet is satisfied with the word 'schools' (szkoty), while in the Latin text they are called 'the Pallas palace' (Palladis aula). The image of Athena Pallas, who is associated with wisdom and sciences, was much admired in occasional literature of the eighteenth century and was often used when speaking of education, reading, and ingenuity.

Although it is more frequent that Latin texts are accompanied by Polish texts, there also exist instances in the reverse. One of them is a group of poems in Korickis's collection. It bears the title 'Przy kolebce J. O. Xiążęcia Adama Szczęsnego Konstantego Czartoryskiego, dnia 15 Stycznia 1770’ ('At the cradle of Duke Adam Felix Constantin Czartorysky'). These poems can be described as an example of the genethliacon ${ }^{10}$. The work dedicated to the young Duke Czartorysky consists of three such poems in Polish, of which only the last - the third one - has a parallel version called 'Latine idem' ('The same in Latin'):

Pośrzod gromów woiennych Xiążę swiatu wschodzi, Wtenczas się, gdy pioruny biią, perła rodzi.

Tak iest, tyś perłą Xiążę nowonarodzony,

Będziesz ozdoba mitry, i polskiey korony. (Korycki 1817: 144)

(Amidst the rolling thunder of wars a duke arrives in the world; a pearl is born at the time of flashing lightning. It is true: you, newborn duke, are a pearl, you will be the ornament of the mitre and of the Polish crown.)

'Latine idem':

Bella tonant, Princeps Polono nascitur Orbi:

Nasci, dum resonant fulmina, gemma solet.

Gemma tu es ipse puer, decus inde biforme futurum

Regum sceptra trahent, et tua mitra ducum. (Korycki 1817: 144)

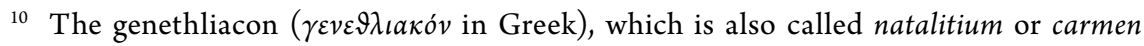
natalitium, is a panegyric verse written to honour a birth. Statius' Silvae (II, 7), Virgil's Eclogae (IV), Tibullus' Elegiae (II, 2) and others are referred to as typical examples of the genre, which is attributed to silvae, epic poetry (poesis epica), and panegyric poetry (poesis panegyrica) (Michałowska 1974: 173). 
(The wars are rolling, and a Polish duke is born: it is usual for a pearl to be born amidst flashing lightning. O child, you are a pearl yourself, and thus royal sceptres and your own mitre will wish you to be an ornament of both.)

Even if the Latin poem is very similar to the Polish original, we can observe several small alterations in the translation: the Latin text names the dedicatee's place of birth directly ('Polono nascitur Orbi'), while in the Polish version it is not emphasized ('Xiąże swiatu wschodzi'). This information is rendered by pointing out that the duke will be 'an ornament of the Polish crown'. Interestingly, the Latin text mentions a sceptre that symbolizes the power of the king ('Regum sceptra trahent'), when a simpler expression suffices in the Polish text ('polska korona').

The epigrams discussed differ not only in the nuances of meaning, but also in their versification. The Latin variants are written in elegiac distich, while the Polish parallels are composed in a thirteen-syllable verse with $a a b b$ rhymes. Discrepancies of this type arise not because of the author's desire to improvise, but for objective reasons: the strophe of both the Latin hexameter and the elegiac distich do not lend themselves to easy translation into Polish.

Another instance of bilingual poetry can be found in the epigrams from a poetry collection dedicated to the afore-mentioned Bishop of Vilnius, Ignatius Masalskis. Structurally, thematically (the themes of the poems are eloquently revealed in their titles), and linguistically, this small collection represents a typical example of an occasional publication of that time. It is printed in the in quarto format popular in the eighteenth century. The graphic image of the emblem of the Masalskis family is printed in the usual place, on the reverse of the title page. The collection consists of nine numbered texts. Presumably it is not incidental that Latin works precede Polish texts. The collection opens with a fairly large (135 lines) poem 'Desiderium omnium' ('The desire of all'), which is followed by the elogium 'Solatium Societatis et Academiae' ('Comfort of the Society [of Jesus] and the Academy'), the poem on the origins of the Masalskis family 'Solatium familiae cujus stemma $M$ litera' ('Comfort of the family the emblem of which has the letter $M^{\prime}$ ), and the emblematic epigram 'Ad Illustrissimum Praesulem votum Societatis Jesu' ('A wish of the Society of Jesus to the most Illustrious Bishop'). These four texts, which make up approximately a half of the whole collection, are written in Latin. The rest of the book consists of the bilingual epigram 'Epigramma in Ignatii Nomen Illustrissimi Antistitis a Minima Societate Jesu' ('Epigram to the name of Ignatius Masalskis, the Illustrious Bishop, written by the Smallest Society of Jesus') and four poems in Polish: the emblematic epigram 'Epigramma na herb [...] Massalskich, $M$ literę, wyrażający zgóry czytającemu figurę Litery $W$ ’ 
('Epigram [...] to the letter $M$ of the Masalskis' emblem, which looks like $W$ to the one who reads it upside down'), a poem expressing the joy of the dedicatee's father Mykolas Masalskis 'Radosc [...] Michała kniaźia Massalskiego [...]' ('The joy of Duke Mykolas Masalskis [...]'), and the epigram 'Doktorowi oboyga prawa Akademia' ('Academy [dedicates] to the doctor of the two laws'). The collection closes with the bucolic improvisation 'Ekloga. Diecezya Wileńska pod imieniem Korydona, zaprasza Pasterza, którego nazywa Alexym' ('Eclogue. In the name of Corydon, the diocese of Vilnius invites the shepherd whom it calls Alexis'), which imitates Virgil's second eclogue 'Ad Alexium', and is dedicated to Masalskis, the new shepherd. The introductory poem of the collection is written in hexameter, other Latin texts, with the exception of the elogium, in elegiac distich; the Polish poems are composed in the thirteensyllable verse with aabb rhymes, as was characteristic of the period.

We will focus our attention on the work of the collection that is most relevant to our research: the bilingual poem 'Epigramma in Ignatii Nomen Illustrissimi Antistitis [...]'. Placed in the middle of the collection, this epigram can be seen to divide it into two parts, the Latin and the Polish. The theme of the epigram is based on the semantics of the word pastor (a shepherd, a pastor). From the early centuries of Christianity, the meanings of this word were used in the works dedicated to the hierarchs of the Church and bishops; the plot 'opposition' of the sheep and the wolf functioned as a locus communis. The epigram opens with references to the death of the former Bishop of Vilnius, Mykolas Jonas Zenkavičius, and the grieving community of believers whose first pastor was Ignatius Loyola. It is undoubtedly a conscious digression, because, on the one hand, this is a way to honour the founder of the Jesuit Order, and, on the other hand, a share of this honour falls to the personality of Masalskis, Loyola's namesake:

Flebat Pastoris nuper grex invida fata:

Grex, cuius primus Dux Loiola fuit. (Massalski 1762: $\mathrm{B}^{3}$ recto) ${ }^{11}$

(Upon the resolve of envious fate, the flock has just wept over the Pastor: the flock whose first Leader was Loyola.)

The short introduction is followed by a narrative describing the vulnerability of sheep who have lost their pastor; the threat to their safety was lifted once the new Bishop was appointed:

11 For the sake of brevity, a modified bibliographical abbreviation is given here. See bibliography under: Illustrissimo [...] Ignatio [...] Massalski. 
The Same in Polish, or Peculiarities of Bilingual Occasional Poetry

Non procul insidians tenero iam stabat Ovili, Atq[ue] cruentato saeviit ore lupus.

Cernis ovans agris ut nunc grex errat apertis Atq[ue] malu[m] sensim territat ille lupum. (Massalski 1762: $\mathrm{B}^{3}$ recto)

(Close to the gentle sheepfold a wolf was lurking, and shortly it attacked, with its blood-stained fangs. You are observing joyfully how now [when you have become a Bishop] the flock spreads in open fields and slowly begins to intimidate the evil wolf.)

The conclusion of the epigram reveals the truth behind the unexpected change:

Noscere vis causam? Massalsci conspice vultum.

Est Ignatius, est Pastor, et ipse Pater. (Massalski 1762: $\mathrm{B}^{3}$ recto)

(You want to know the reason? Look at Masalskis' face: it is Ignatius; it is the Pastor and the Father himself.)

The Polish variant of this epigram is twice as long as the Latin one. It comprises two equal strophes (eight lines each), which are traditionally called 'The same in Polish' I and II. Since the first strophe is basically a word-for-word translation of the Latin epigram, we will not comment on it. The second strophe can be considered a free improvisation on the theme, in which the motif of the sheep and the wolf is omitted and only the semantics of the bishop as a pastor is retained. The original content is complemented with new and relevant information related to Masalskis' activities, while the link of this strophe with the Latin original is conveyed by the generalisation found in the closing lines:

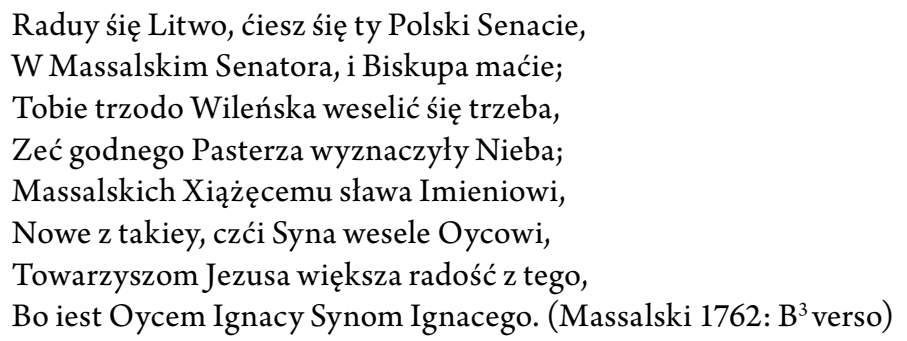

(Rejoice, Lithuania; rejoice you, the Polish Senate, too; you have Masalskis both as a Senator and a Bishop. You, the flock of Vilnius, should be merry, because Heavens have appointed a worthy Pastor. Glory to the name of the dukes Masalskis, thanks to Son's glory the Father's heart is overflowing with joy. Therefore the members of the Society of Jesus rejoice even more [over the new Bishop], because Ignatius is [like] Father to Ignatius' Sons.) 
The observed semantic differences influence the general mood of this strophe. Compared with the Latin original, the Polish version is pedestrian, but strikes as more intimate tone.

This essay highlights the important peculiarities of bilingual poetry, but does not yet allow us to draw broader generalizations. This task will be possible when we gain a larger picture - from the point of view of both genre and language of eighteenth-century bilingual occasional literature of the Grand Duchy of Lithuania. The target group of works - Latin texts with parallel variants that the authors themselves refer to as 'The same in Polish' - limits the scope of the research. Works of this type are particularly useful since they relieve the scholar from the duty of measuring the degree of identity with the parallel text.

Analyzing texts of bilingual occasional poetry does not allow us to confirm Eugenija Ulčinaitès conclusion that parallel variants are independent works. The observed semantic differences are not essential. However, the very fact of their existence presupposes the author's preconceived intention to write a text that would be understood by an individual from a different cultural background - a noble task to enlighten those who lack classical education or are members of the general public.

The poets of the eighteenth century were educated in the tradition of humanist education and were familiar with various aspects of poetics and style. By expressing the same content differently, they did not digress from the original, but they did engender semantic and stylistic differences in the text: the authors replaced classical images with analogies or simpler wordings that were closer to the cultural context and supplied additional dedicatee-related information that affected the mood of a work.

Bilingual texts were published without attribution: they could have been penned by the author of the original text, or by different authors. The examples chosen for the analysis make it possible to argue that the identity of parallel works is determined not by the author, but by the dedicatee.

It is important to note that bilingual occasional poetry evolved and existed as a spontaneous phenomenon responding to natural cultural needs, and was not regulated by poetics and rhetoric. These works, therefore, are a valuable illustration of the development of society's intellectual culture. 
The Same in Polish, or Peculiarities of Bilingual Occasional Poetry

\author{
Asta Vaškelienè \\ asta@llti.lt \\ Lietuvių literatūros ir tautosakos institutas \\ Antakalnio g. 6 \\ LT-10308, Vilnius \\ LIETUVA / LITHUANIA
}

\title{
Bibliography
}

Encyklopedia wiedzy o jezuitach na ziemiach Polski i Litwy 1564-1995, opracowa1 Ludwik Grzebień SJ przy współpracy zespołu jezuitów. 1996. Kraków: Wydawnictwo WAM.

Illustrissimo [...] Ignatio [...] Massalski, episcopo Vilnensi, Academia et Universitas Vilnensis S. I. tanquam suo cancellario in ejus solemni consecratione plaudens A. 1762 d. 2 Maji.[1762]. [Vilnae]: [s. 1.].

Korycki, M. 1817. Michaelis Korycki Societatis Jesu Sacerdotis Carmina. Polociae: Typis Academicis S. J.

Kostkiewiczowa, T. 2008. Dirae. - M. Głowiński, T. Kostkiewiczowa, A. OkopieńSławińska, J. Sławiński, Słownik Terminów Literackich. Wrocław [i in.]: Zakład Narodowy im. Ossolińskich, 101.

Michałowska, T. 1974. Staropolska teoria genologiczna, (Studia staropolskie, t. 41). Wrocław [i in.]: Zakład Narodowy im. Ossolińskich.

Okopień-Sławińska, A. Leoniny. - M. Głowiński, T. Kostkiewiczowa, A. OkopieńSławińska, J. Sławiński, Słownik Terminów Literackich. Wrocław [i in.]: Zakład Narodowy im. Ossolińskich, 274.

Petrauskienè, I. 1976. Vilniaus akademijos spaustuve 1575-1773. Vilnius: Mokslas.

Stryjkowski, M. 1582. Kronika Polska Litewska, Zmodzka, y wszystkiey Rusi Kijowskiey, Moskiewskiey, Siewierskiey, Wotynskiey, Podolskiey, Podgorskiey, Podlaskiey, etc. Y rozmaite przypadki woienne y domowe, Pruskich, Mazowieckich, Pomorskich, y inszych krain Krolestwu Polskiemu y Wielkiemu Xięstwu Litewskiemu przyległych [...]. Królewiec: Georg Osterberger.

Ulčinaitè, E. 2006. Lietuvos Didžiosios Kunigaikštystès XVI-XVII amžiaus dvikalbis tekstas: adresatas ir kalbinè raiška. - Senoji Lietuvos literatūra, 21, 63-80.

Universitas linguarum magno Palaemonii orbis et urbis hospiti [...] Christophoro Joanni [...] Szembek [...] proposita ab Academica Universitate Vilnensi Soc. Jesu. [1729]. [Vilnae]: [s. 1.]. 